\title{
Women in politics: emotions and challenges in complex institutional dynamics
}

\author{
Camilla Fernandes ${ }^{1}$ \\ MARIANE LEMOS LOURENÇO ${ }^{1}$ \\ SAMANTHA FROHLICH ${ }^{1}$ \\ DIOGO ESPEJO DA SILVA ${ }^{2}$ \\ FLÁvia OBARA KaI ${ }^{1}$
}

${ }^{1}$ Universidade Federal do Paraná (UfPr) / Programa de Pós-graduação em Administração, Curitiba - PR, Brazil

2 Universidade Federal do Paraná (UfPR) / Escola de AdMinistração, Curitiba - PR, Brazil

\begin{abstract}
Seminal studies about institutional theory highlighted the focus on cognitive issues in research on institutions. However, during the last few years, a growing body of literature has also been devoted to understanding the role of emotions in institutional dynamics. In one of the classic texts on institutional theory, Scott emphasizes three institutional pillars, the regulatory, the normative, and the cognitive. Researchers point out that there is now a fourth pillar: the role of emotions in institutional theory. This article explores the emotions' role in institutional dynamics, especially related to women's political participation in the 2018 Brazilian elections. Three cases of female candidates who showed high performance in pre-election polls, were discussed. The research analyzed the candidates' interviews and social media, observing their emotions in publications and expressions. Also, emotional expressions of society toward the studied candidates, as well as expressions potentially reflecting the institutional dynamic present in the Brazilian political arrangement, were analyzed. The main results show that during the 2018 Brazilian electoral campaign, in the face of the institutionalization of a masculine environment on the political scenario, the society expressed emotions of hatred and aggression against the three candidates since they violated institutional arrangements about behaviors considered acceptable in the dominant institutional logic. Despite this, two of the three female candidates were elected with the highest number of votes in their states, surpassing their male competitors. The candidate who was not elected obtained a significant number of votes.
\end{abstract}

Keywords: Woman in politics. Institutional dynamic. Brazilian elections. Emotions.

\section{Mulheres na política: emoções e desafios em dinâmicas institucionais complexas}

\section{Resumo}

Estudos seminais sobre a teoria institucional destacaram que pesquisas sobre instituições têm se concentrado em questões cognitivas, entretanto, durante os últimos anos um corpo crescente de literatura também tem se dedicado a entender o papel das emoções na dinâmica institucional. Em um dos textos clássicos sobre a Teoria Institucional, Scott enfatiza três pilares institucionais, o regulatório, o normativo e o cognitivo. Pesquisadores apontam que agora ter-se-ia uma quarta ênfase: o papel das emoções na Teoria Institucional. Considerando o exposto, o presente artigo explora o papel das emoções nas dinâmicas institucionais, especialmente quanto à participação política das mulheres nas eleições brasileiras de 2018. Discute-se três casos específicos de mulheres candidatas com as maiores intenções de voto nas referidas eleições, levando em conta entrevistas, mídias sociais informações divulgadas publicamente buscando publicações e expressões de emoções não só delas, mas também da sociedade que poderiam refletir a dinâmica institucional presente no arranjo político brasileiro. Os principais resultados demonstraram que durante a campanha eleitoral brasileira de 2018, diante da institucionalização de um ambiente masculino no cenário político, a sociedade expressou emoções de ódio e agressão contra as candidatas analisadas neste estudo, uma vez que elas violaram arranjos institucionais de comportamentos considerados aceitáveis na lógica institucional dominante. Apesar disso, duas das três candidatas a cargos políticos foram eleitas como as candidatas mais votadas em seus estados, alcançando mais votos do que concorrentes masculinos, porém a última não foi eleita apesar de ter obtido expressivo número de votos.

Palavras-chave: Mulheres na política. Dinâmica institucional. Eleições brasileiras. Emoções.

\section{Mujeres en la política: emociones y desafíos en la compleja dinámica institucional Resumen}

ELos artículos seminales sobre la teoría institucional resaltaron que los estudios sobre instituciones se han centrado en cuestiones cognitivas. Sin embargo, durante los últimos años también se ha dedicado una creciente cantidad de investigación y comprensión del papel de las emociones en la dinámica institucional. En uno de los textos clásicos sobre teoría institucional, Scott enfatiza tres pilares institucionales: el regulador, el normativo y el cognitivo. Los investigadores señalan que ahora habría un cuarto énfasis: el papel de las emociones en la teoría institucional. El presente trabajo explora el papel de las emociones en las dinámicas institucionales, especialmente la participación política de mujeres en las elecciones brasileñas de 2018. Para ello, se discuten tres casos específicos de candidatas con las intenciones de voto más altas en las citadas elecciones, teniendo en cuenta sus entrevistas y redes sociales, buscando publicaciones y expresiones de emociones no solo de ellas, sino también de la sociedad que podrían reflejar la dinámica institucional presente en el arreglo político brasileño. Los principales resultados han demostrado que durante la campaña electoral brasileña de 2018, ante la institucionalización de un ambiente masculino en el escenario político, la sociedad expresó emociones de odio y agresión contra las candidatas analizadas en este estudio, ya que violaron los arreglos institucionales de comportamientos considerados aceptables en la lógica institucional dominante. A pesar de esto, dos de las tres candidatas a cargos políticos fueron elegidas como las candidatas más votadas en sus estados, alcanzando más votos que los competidores masculinos; la última no fue elegida, a pesar, de haber obtenido una cantidad significativa de votos.

Palabras clave: Mujeres en la política. Dinámica institucional. Elecciones brasileñas. Emociones. 


\section{INTRODUCTION}

According to Toubiana and Zietsma (2017), since the seminal article by DiMaggio and Powell (1983) and Meyer and Rowan (1977), studies about institutions have focused on cognitive issues; however, during the last few years a growing body of literature has also been devoted to understand the role of emotions in institutional dynamics. In one of the classics studies related to the Institutional Theory, Scott (2013) highlighted three institutional pillars: the regulative, the normative and the cognitive. Toubiana and Zietsma (2017) argue that now we have a fourth emphasis: the role of emotions in the Institutional Theory. So, this paper aims to explore the role of emotions in related institutional dynamics, especially the political participation of women in the 2018 Brazilian elections.

The political arrangements that have prevailed in Brazil are based on an institutional dynamic of "strong patrimonialism tradition associated with a long authoritarian period during its socio-cultural formation process" (MACHADO and GONÇALVES, 2007, p. 224), where its political scenario has been marked by the predominant presence of men. It should be noted that all over the world the participation of women in politics is relatively lower than that of men (ROMERO and KERSTENETZKY, 2015) as well as their electoral support (BAUER, 2020).

However, when it comes to Brazil, it is perceived that the perfomance of women in politics is a troubled subject. It is possible to verify this situation when analyzing the last ranking of female representation in congresses conducted by the Inter-Parliamentary Union (2019), in which Brazil holds the $132^{\text {nd }}$ position of the 235 countries surveyed.

Therefore, to reach the goal of this research it was investigated the role of emotions in the institutional logic of the Brazilian political arrangement and how it could influence the emotions of women candidates who have attempted to run for political positions, as well as the emotions that society as whole (of all genders) expressed in relation to these women, to be possible to analyze what is the role of emotions in this institutional dynamic. It is important to highlight that institutional logics based on patriarchalism developed aggressive emotions in the Brazilian society in 2018 elections, manifested in behaviors of violence expressed in social networks, against these women candidates, as will be described in the discussion of this article, this episode may have triggered in these women "emotional-lande influence activities of shaming and shunning" (VORONOV and WEBER, 2016, p. 2), as will be discussed in this study.

It should also be highlighted that in this paper institutional logic is seen as the socially shared assumptions and values that provides repertoires of habits, skills and styles that condition the actions to be performed in institutions and may even involve specific emotions (TOUBIANA and ZIETSMA, 2017).

We focused on three specific cases of women candidates with the highest voting intentions of Brazil's 2018 elections. Inside of political arrangements with "institutional patrimonialistic dynamics" (based on the domination and protection of men), women had to deal with prejudices, challenges, threats and other negative issues that came through social media, which directly influenced their emotional aspects. According to Voronov and Weber (2016), it is important to emphasize that emotions are central to human experience and scholars have increasingly recognized their role in institutions, which affirms the importance of this topic of study to the academic community.

The main results showed that because of a political environment with a sexist culture rooted in patriarchy, less women are involved with politics; therefore, there is no greater potential for change in this environment. Political women were subjected to pressures, expressed by negative emotions of hate and aggression in social networks, throughout aggressive fake news, suffering threats even to their physical integrity, which generated public emotions declared of fear and awe.

The results also revealed that many people in Brazil have expressed negative emotions of aggression and hatred to these women by openly sharing fake news, not hiding their names or personal information through social networks. However, some of the threats to the candidates, especially the ones of physical integrity, such as death threats, have come anonymously, and are under investigation. Toubiana and Zietsma (2017), in quoting the work by Creed, Hudson, Okhuysen et al. (2014, p. 285), stressed that people with "cognitive, emotional and/or moral commitments" inside institutional arrangements will police the limits of acceptable behavior, trying to embarrass people (in this paper, women) who violate such arrangements to "reinforce required standards and/or punish offenders".

Thus, the main contributions of this study are: (1) examining the role of emotions in a scenario of institutional complexity; (2) emphasizing that, although men and women sometimes occupy unequal roles in society (VERAS, 2018), 
changes are becoming increasingly necessary in all aspects; (3) also, offering contributions about the "role social media might play in disrupting organizations in complex institutional settings" (TOUBIANA and ZIETSMA, 2017), which can be considered a research gap because "few organizational scholars have examined" (TOUBIANA and ZIETSMA, 2017) this issue.

In regards to women candidates for political office in Brazil's 2018 election, this study focused on three candidates: two of them were elected as the most voted candidates in their respective states, reaching more votes than the male competitors; and the other one was not elected despite having obtained an expressive number of votes.

\section{THEORETICAL FRAMEWORK}

\section{Women in politics}

The under-representation of women in the political environment is a constant concern throughout the world (ROMERO and KERSTENETZKY, 2015). It is known that the gender of political representatives has influence and relevance concerning which aspects will be prioritized and which policies to formulate (GRANT, KESTERNICH, STECKENLEITER et al., 2018).

Faced with this reality, some countries have made a series of changes, mainly in their legislation to encourage an increase in the number of women in political positions in order to reverse female under-representation. An example of such changes includes the minimum quotas that some countries have in order to establish that a percentage of $30 \%$ to $40 \%$ of the candidacies must be reserved for female candidates (IDEA, 2018). Over the past 20 years, the percentage of women elected worldwide has increased significantly in comparison to previous years, however, only $24 \%$ of political positions were held by women during the year 2018 (INTER-PARLIAMENTARY UNION, 2019; NG and MUNTANER, 2018).

Conversely, institutional aspects of the electoral and party system, such as the quota model adopted, can limit the potential for women's participation in the political field as shown in studies by Araújo (2010), relating her results to Brazil. For the author, from an "institutional" perspective, the results would also and perhaps to a greater degree, result from party decisions 'mediated by' and 'derived' from the interaction between the type of electoral system and the party system (ARAÚJO, 2010, p. 568). One electoral system can be an open or a closed list: The open list is a system of proportional representation voting where voters vote for parties and in the order of candidates on that party's list, while the closed list is the system in which one votes for parties and not for candidates. It should be noted that the scenario analyzed by the author takes into account countries such as Brazil and Argentina. In Brazil, the system would be an open list, and in Argentina, a closed list. For Araújo (2010, p. 568), the closed list "meets better conditions for the realization of quotas. These conditions would be given by the fact that the closed list avoids the so-called intra-party dispute and by the chance to include women in the first spaces of their order, thus ensuring good chances of election".

In spite of this, it was only in 1893 that the political scenario was changed. This was the year that New Zealand recognized the right of women to vote, followed by Finland in 1906. When it comes to the American context, the United States recognized in 1919 the female vote defined by means of an amendment to its constitution, and Ecuador was the first Latin American country to allow female citizens to vote in the year 1929 (TOSI, 2016).

However, since women were allowed to enter the political environment, they faced a number of challenges in dealing with the many historical issues rooted in this system. It is not only the prejudice of being a woman, but several barriers that oppose their permanence and attempts to change the dominant logic within this scenario (ZAKAR, ZAKAR and HAMID, 2018).

The gender issue ends up being great, but it is not the only difficulty for the attempt to enter in politics that women face and because of several bad positions coming not only from those who are already included in the political environment but also, on the part of the population, the participation of women ends up being retracted. Women still are treated as too sensitive and emotional for leadership positions, and this kind of positioning is contrary to the expectations of the population who often expect politicians to have more brutal and aggressive stances. However, it is relevant to emphasize that women have different qualifications, experiences and positioning from men and this influences directly the acceptance that they will have, considering that politics is a predominantly masculine and highly competitive environment (COSTA and SCHAFFNER, 2018). 


\section{Women in Brazilian politics}

The Brazilian political environment is marked by being predominantly male and has as its institutional dynamic a "strong patrimonialism tradition associated with a long authoritarian period during its socio-cultural formation process" (MACHADO and GONÇALVES, 2007, p.224). These institutional aspects embrace cognitive issues when women who become involved in politics become aware of, and, understand this field. Regarding this issue, emotional aspects are highlighted concerning the entrance in a field still so adverse to politician women around the world, as well as in Brazil (ARAÚJO, 2012) since for a long time, the Brazilian political environment has been perceived as that of the male's world (MIGUEL AND FEITOSA, 2009).

This occurs because the insertion of women into politics in the country began with the struggle for the right to vote in 1891, when 31 constituents signed an amendment to the current Constitution that would confer the female right to vote, but this amendment was rejected (TOSI, 2016). The elections in the country occur since 1532, however, it was only through the constitution of 1934 that Brazilian women had the right to exercise their votes without restrictions, because, for a long time the suffrage was not seen as a right, but as a privilege that could only be attributed to the "political head of the family" (CAJADO, DORNELLES and PEREIRA, 2014).

The struggle for women's suffrage in Brazil was not only engaged by women but also by various intellectuals, politicians and religious authorities. As a result of all these battles, in 1932 women were initially able to vote through the Electoral Code signed by President Getúlio Vargas; however, the vote was optional and could only be exercised if authorized by the responsible man (TOSI, 2016).

Despite this history and a reputation marked by machismo and deep gender inequalities, Latin America is now considered the region of the world that has elected more women presidents - the highest position in democracies - in comparison to the whole world, having done it seven times since 2006 in the following countries: Chile, Argentina, Ecuador, Bolivia, Costa Rica, Nicaragua and, finally, Brazil (REYES-HOUSHOLDER, 2018).

In an attempt to encourage greater participation, in 1997 it was approved the law number 9.504, which stipulates that in elections, each party or coalition of the country must have at least $30 \%$ of its candidacies filled by women. However, this law defined that the percentage of place reservations would be on the potential list of applications and not on the final quantity of candidates, losing its strength and effectiveness. It was then in 2009 with Law number 12.034 that it officially became mandatory to fill $30 \%$ of applications with women, which resulted in a significant increase in the number of women candidates compared to previous years. But even so, the design of such legislation opened loopholes for applications filled only in formal requirements, making "orange applications" still exist. This problem led to the perception that in order to maximize the effectiveness of the quotas, it was necessary to link investment. Thus, in the 2015 political reform that resulted in Law number 13.165, parties were expected to commit a minimum of $5 \%$ of campaign resources to women's candidacies and $15 \%$ of all party fund resources earmarked for this purpose. With the intention of verifying the effects and effectiveness of these legislative changes, the results of the 2016 municipal elections were analyzed, and, although female candidacies have increased, the total participation is still very low because, currently, there are seven city male councilors for every female one (TSE, 2018). In federal and state positions, the situation is not different taking into account that only $15 \%$ of the positions are filled by women (INTER-PARLIAMENTARY UNION, 2019).

Considering that the Brazilian political context was based primarily on a predominantly masculine patriarchal institutional dynamic, in the next section some elements of institutional theory that help to understand this prevailing institutional logic are explained. We emphasize that the entry of women in this scenario is characterized as a disruptive event bringing two conflicting institutional logics to the Brazilian context: one of them has predominance in the patriarchal tradition and the other encourages and marks the entry of women in this field, bringing new logics that are marked by a new ethos and complex emotional processes of society in response to these logics. In sequence, the concepts of institutional logics, ethos, disruptive events and the emotional processes that permeate these issues are presented. 


\section{Contribution from the Institutional Theory and emotions}

The Institutional Theory according to Voronov and Vince (2012), is implicitly based on the assumption that the connection between people and institutional order is of cognitive or habitual nature. It took some time to incorporate that "institutions depend, both in their formation and at their core, on passionate identification" (FRIEDLAND, 2012, p. 593). The goal of a passionate identification is what is called the institution's ethos, which defines an institutional order in terms of its principles of moral and ethical values (VORONOV and WEBER, 2016).

Participants of an institutional order may strive to maintain their connection with the ethos in their experiences. The effectiveness of this as a mechanism of disciplinary power over the participants of an order is improved as some people can be pointed out as examples or personifications of the institutional ethos. The concept of ethos can be considered complementary to the concept of institutional logic since institutional logic is central to understand the lived experience as well as the emotional dynamics inside institutions. People tend to defend the logic in which they are inserted, especially because they may feel connected both emotionally and ideologically to it (VORONOV and VINCE, 2012; VORONOV and WEBER, 2016).

In this defense of institutional logics where people are inserted, Araújo (2010, p. 581) highlights that in Brazil, "there are deep-seated perceptions that power is for men", and, many people can feel a connection not only ideological, but also emotional with these aspects, this is a question raised in the present article in relation to the Brazilian society (of all genders), which expressed emotions of hatred in social networks in relation to women who ran for political positions in 2018.

In this paper, the authors understand institutional logics as the socially shared assumptions and values that are deeply ingrained, forming a framework that provides legitimacy and allows organizing time and space. The logics provide repertoires of habits, skills and styles that, in turn, condition the actions to be performed in institutions, and may even involve specific emotions (TOUBIANA and ZIETSMA, 2017).

Institutional logics condition what should be done, and in this sense, the ethos is responsible for capturing the "spirit" or "character" of an institutional order in which people identify and develop a sense of belonging (VORONOV and WEBER, 2016).

Inside the institutional logic, a series of behaviors are mainly expected in what refers to responses to "disruptive" events, which can trigger all kinds of emotions (TOUBIANA and ZIETSMA, 2017). In this context, people with cognitive, emotional, and/or moral commitments with institutional arrangements will monitor the limits of acceptable behavior with a commitment to enforce the norms established therein and avoid transgressions (CREED, HUDSON, OKHUYSEN et al., 2014). Each individual, responding to institutional elements, behaves in a way that empowers, guides and motivates others to behave similarly, taking with them institutional elements and passing them through (SCOTT, 2013).

Emotions end up having an important role in this scenario because it is through emotional practices that people construct and realize their social "me" (CREED, HUDSON, OKHUYSEN et al., 2014). Emotions can be defined as an "umbrella" term - and should be pointed out that some authors define it as affective processes - which comprise a wide scope of feelings that individuals can experience regarding a specific moment, a short-term affective experience or some feeling traits that can or not be stable (BARSADE and GIBSON, 2007).

Taking this into consideration, it is important to highlight the existence of fear and anger. Fear is a common and powerful emotion (GILL and BURROW, 2017) and represents a response to an imminent threat (DSM-V, 2014), being described as appraisals of low certainty, lack of individual control, and high-anticipated effort (SINGH, GARG, GOVIND et al., 2018).

Anger, on the other hand, can influence the judgment and decisions of the person who experiences it, considering that people find it difficult being angry at the right time, for the right purpose, and in the right way. Instead, they have the tendency to feel confident and thinking the worse of others and, in some situations, these may have undesirable outcomes such as aggression, for example (LERNER and TIEDENS, 2006).

In this sense, "institutional fear" means that fear and the rules related to the experience of fear can be distributed throughout social groups and communities over time (GILL and BURROW, 2017). With all the content exposed, in the next section we present the methodological procedures used in this study. 


\section{METHODOLOGICAL PROCEDURES}

This research is based on a qualitative approach since it represents a way of understanding what are the meanings attributed to specific events by its participants, considering there is an existence of a subjective nature of the being that should be studied (CRESWELL, 2017).

The qualitative research approach seeks to understand different aspects related to phenomena in an in-depth manner (GIBBS, 2009), being considered a coherent way of perceiving the properties of a social phenomenon. A social phenomenon is in accordance with the particularities of qualitative research because it embraces personal experiences, life stories, texts and cultural productions, among others, which represent usual and adverse circumstances (RICHARDSON, 1989) as was the case of the Brazilian candidates in the 2018 elections.

In order to achieve the proposed objectives, the present study used primary and secodary data. The primary data were collected through a semi-structured interview with one of the women selected, since this type of interview allows a greater flexibility to the interviewer as well as a better use of the dialogues production (BRINKMANN, 2018). The interview was conducted in person, recorded and later transcribed with the purpose of obtaining a better understanding of what was exposed.

The secondary data, that in this case are related to the other two cases, the emotions expressed by these candidates and the emotions about the population relating to them, were collected through information disclosed in the Brazilian media, mainly from interviews granted to the Brazilian press media by the candidates analyzed. The researchers analyzed information on their respective social media either, as Facebook, Instagram and YouTube. In addition, we also used journals that have published interviews and articles about the women whom this paper focuses on. In these materials, we researched the expression of emotions by the candidates and emotions society has expressed (men and women) that were directly related to these candidates as well as newspaper articles that reported about fake news and advertisements that expressed hateful content to these women.

The selection of the materials for the analysis occurred during the months of April 2018 to September 2019 and, the interview was granted in December of 2018. It is important to emphasize that all the documents collected and used in this study are in public domain. It should be noted that the present study analyzes the statements of three women who ran for different electoral positions in the elections held in 2018 in Brazil. All the candidates have antagonistic political positions and yet have been assaulted with verbal aggressions and threats. To protect their identities they were named as G.A.; C.A. and D.A.

The three candidates were selected not only because of their positions and relevance in the election's context but especially because of the exposure to attacks. Although other candidates also suffered and reported attacks, those used as the focus of this study were candidates who received large amounts of votes in their respective states. They all faced unusual and adverse circumstances for women candidates in the referred election, which was a very polarized election and it was the eighth national election after the re-democratization of Brazil. In this study, we do not intend to explore the polarization itself, but the difficulties faced by female candidates in this relevant election, which were linked to the condition of being a woman and the complex institutional dynamics in the political scenario. The examination of documents such as those mentioned above bring important contributions to the qualitative research (CRESWELL, 2017), especially for this work, because it reveals significant aspects of Brazilian society, mainly focused on the emotions demonstrated.

For the analysis, in order to manage data, we used the analysis of content which allows the interpretation of subjective aspects related to the content itself, using a set of diverse methodological instruments that apply to different types of discourse. With the content analysis, the researcher's goal is to examine aspects such as frequency and correlation existing in a body of data that can bring the interpretation of latent meanings. This form of analysis goes beyond the apprehension of the simple frequency of the themes present in the texts, deeming necessary to unveil the people, their stories, their thoughts, their arts and their institutions (RICHARDSON, 1989; SALDAÑA and OMASTA, 2016).

Thus, content analysis contributes to human sciences, and has become an essential way to understand the living society, in permanent interaction (RICHARDSON, 1989). The documents selected for the analysis were organized according to their themes, and the selected videos were transcribed and organized by content. The analysis of the documents, coming from newspaper news, videos, public messages on social networks, revealed for the analysis, decisive and dramatic moments/events for the three candidates receiving larger number of votes in the 2018 election. 


\section{ANALYSIS AND RESULTS}

According to the data presented previously, the political sector in Brazil is predominantly male and it is verified that because of issues that are already rooted in, the entry of women is difficult, as well as their permanence in this field. This fact needs to be overcome in Brazil and others countries, since the participation of women is a right to be won and preserved all over the world.

The three cases presented here refer to different candidates who suffered a series of incidents during the 2018 Brazilian elections. The first case presented is about the candidate called G.A. who in a television interview during the pre-election campaign, suffered a series of assaults before being officially launched as a candidate. The televised program in question invited G.A to talk about her plans and intentions regarding her candidacy for the party which she was affiliated to, but it ended up going through a series of constraints (STYCER, 2018). According to the newspaper Folha de São Paulo (2018), G.A. was interrupted at least 40 times during the 80 minutes of the program, the equivalent of once every two minutes. It should be noted that, in the same program, other candidates were interviewed and the one that was most interrupted after G.A., obtained a total of nine interruptions in the same period of time.

Returning to what was highlighted by Creed, Hudson, Okhuysen et al. (2014), this situation exposes an attempt to embarrass people, to reinforce norms and to punish the transgressors, in this specific case, to shame the woman candidate to a political position, for transgressing the culturally instituted norm of men hegemony in Brazilian politics.

Later, already in campaign season, G.A. suffered a series of attacks, mainly through the spread of fake news slandering her image with collages and edited videos disseminated by opponents in social networks. This fact obliged her to publish a video in her defense proving that the videos and news on social networks were all false: "They attack me [...] as everybody has been following the whole campaign, I am the favorite target of these ridiculous collages on the internet"- one of the pronouncements of the former candidate.

In addition, 38 user profiles were created in a social network with offensive content against G.A., as well as aggressive and hateful messages. The behavior of the users exposes what was discussed by Lerner and Tiedens (2006) about how people who are experiencing anger against some event can have a difficult time being angry and can express their emotions in the wrong time, the wrong way and with the wrong purpose. It was possible to see that the results of this fact had undesirable outcomes. The profiles were denounced and blocked by the Electoral Justice in Brazil (TSE, 2018) but, even though the fake news scattered, they have damaged her image before society, as reported "They destroyed my body, manipulated my words, made people who known me break relations with me for believing in these false news".

It is important to point out that G.A has been in the political environment for 14 years and, the election of 2018 was the seventh one in which she ran. One of the points highlighted by her in interviews referred to society's reaction to the fake news disseminated, noting that this is positive news that made her believe that there is still hope even if, in these last elections there have been reports of intolerance. The candidate explained that the people manifestation is mainly due to increased access to information shared in the internet, which is different from past elections where the only source of information were in printed newspapers and television and she also highlighted that "The lies generate anger, violence and intolerance (...) Brazil and the Brazilian people are much better than that".

Even with all the bad repercussion of the false information disseminated, G.A demonstrated courage by challenging them and reported that this fact would not be able to take her down, because, as she told in one interview, most of the messages were moralistic, sexist and misogynist with the purpose of diminishing her image before society. It should be pointed out that G.A reported that this was not the first time that she has been dealing with threats: "My life has already been changed for a long time". This fact confirms that when women enter politics, they have to confront a lot of challenges and barriers against their permanence as exposed by Zakar, Zakar and Hamid (2018).

The G.A case also highlighted what was exposed by Toubiana and Zietsma (2017), when the institution have a disruptive event in this case, the insertion of women in the political scenario - it can trigger all kinds of emotions and not only emotions but also some behaviors that can be seen with the fake profiles that spread the false news.

One of the reasons that lead women not to be welcomed in the political environment is that Brazil has a masculine culture rooted in the historical strength of patriarchy (TELES, 2017), also when women take certain positions, they end up receiving a series of threats. This leads us to emphasize what happened with the candidate called D.A., who exposed to us in an interview 
that she has already suffered a series of threats because of her position in favor of human rights on issues involving violence against women and children. However, the candidate stated that although this is a critical situation, it was essential to engage in this specific cause, mainly because of her position as a people's representative, and according to her: "it is necessary to have courage but, people usually are afraid". The D.A case leads us to reflect about the fact that women can have different positioning to men and, as highlighted by Costa and Schaffner (2018), this can influence the acceptance by the population and other ones that work in this environment.

Later, when asked in the interview about her feelings regarding the threats she suffered and if she would consider leaving the political field, D.A. replied: "I am not irreplaceable but at this moment I am making a difference in this place ... so I need to have the strength to face this kind of situation". It was possible to see regarding what was exposed by D.A that the response corresponds to an evoked mood with a positive feeling (BARSADE and GIBSON, 2007) especially because, as exposed, she believes that it is necessary to face challenges to do bigger things.

The last case in question, highlights a fact experienced by the candidate C.A., who during an interview published in social networks, was questioned by a reporter about her fears and about having received threats. C.A. said in the interview that she felt fear because of the threats to her daughter "of death, with a refinement of cruelty that is not even worth saying." Due to the threats, the candidate removed her family from Brazil, because it was not possible to know if the threats were real or fake. It should be pointed out that during the last electoral campaign, C.A stated that her and her family had to move addresses four different times, stating "No matter where I go, they always end up finding me" reinforcing the idea of fear during the election period.

After the episode, C.A emphasized that she was oriented to change her agenda regarding public appearances until the case was solved. When the interview was granted, C.A. stated that at that moment she was no longer frightened despite the intensification of threats, because, according to her: "I didn't face small things in this life to get here, it's not going to be a threat, people saying they will pull my rug or that they will shoot me that they will stop me. I will move on with my mission, I have a mission with this country, a commitment to people, and I will follow my mission, no matter what is the cost".

In addition, C.A reported in the interview that she has suffered a series of verbal aggression by her party colleagues insinuating she was incompetent to be a candidate, taking this into account, the candidate said: "This kind of threat does not intimidate me, they barely know what I'm capable of", reinforcing that woman in leadership positions are still underestimated by others (COSTA and SCHAFFNER, 2018). Referring to that, she stated that she would like to work until women "always renegades in the political environment" get the chance to work there just like her "without quotas".

C.A also points that politics is popularly known as a dirty place "Women need to go there and clean up the mess", "they need to impose themselves and that's what I want to do, teach that they don't have to let anyone raise their voices against them."

The entry of women gave a more complex institutional dynamic to the political sphere, with two logics. A predominant logic based on patriarchalism, and another one that gives women the incentive and legitimacy in this scenario. In the 2018 Brazilian elections, the entry of women as candidates to political positions caused emotional responses of aggression, expressed mainly in social network. A similar aspect was also found in the study by Toubiana and Ziestma (2017), who studied how "members" and "leaders" show emotional responses and influence activities in response to a disruptive event led to a violation of expectations; in their paper the authors explored "how emotions influence organizations in situations of institutional complexity".

Although women's participation in politics has been taking place since 1934, it was only in the 2018 elections that women won the largest amount of votes in the country and stood out in the media. The expressive vote that the candidates received, and the great amount of fake news and aggressions that they suffered may give indications that their participation in the political environment is a disruptive event (TOUBIANA and ZIETSMA, 2017). Thus, aspects highlighted within the institutional logics of Brazilian politics can become a barrier to women's participation in politics, such as the one highlighted by Araújo (2010, p. 581) that there are "deep-seated perceptions that power is for men". If, as the author points out, there is a perception that power is already considered male, it is difficult for other excluded groups or outsiders to be motivated to participate in such a system, a fact that reaffirms another barrier: the existence of political fiefdoms that are still a strong feature of this environment (ARAÚJO, 2012) preventing the existence of new entrants to the field who do not have political ties, as is the case of two of the women candidates selected for this study. However, it is noticeable that the "political fiefdoms" are formed from parties with an imbalance in campaign financing, as expressed in the work by Sacchet (2018), which triggered in Brazil the need for changes in legislation (BRASIL, 1997, 2009, 2015) because of its impact on the representation of women and minority groups. 
Not only but also considering the role of emotions in this institutionalized environment, the expression in social networks of hatred by part of the Brazilian society to women candidates for political office in 2018 may be considered as a barrier to women's political participation in Brazil, because when women see other women being assaulted for their political participation, they may feel discouraged from also running for political office. The aggressions suffered by the women candidates selected for this study, generated in them emotions of fear and awe, these emotions were reported, when they suffered threats to their physical integrity, and, death threats and violence directed to their family.

In relation to women and men in the Brazilian society who assaulted the women candidates, these people are inserted in a context in Brazil, as highlighted by Araújo (2010, p. 581) and mentioned above, where "there are deep-seated perceptions that power is for men". We could confirm as verified by Voronov and Vince (2012) that people tend to defend the logic in which they are inserted, especially because they may feel connected both emotionally and ideologically to it.

Among the three women who participated in this study, two of them were elected and, despite also receiving an expressive number of votes, the last one was not elected.

\section{CONCLUSION}

In the Institutional Theory view, institutions "try" to provide order and stability (SCOTT, 2013) in face of an institutional logic that connects individuals emotionally and ideologically to them (VORONOV and WEBER, 2016; VORONOV and VINCE, 2012). However, disruptive events that violate institutionalized expectations can trigger emotions which can affect this logic (TOUBIANA and ZIETSMA, 2017).

As emotions are central to human experience, they can directly influence positions that are taken in any environment where the individual inserts themselves (VORONOV and WEBER, 2016). Emotions, therefore, directly affect experiences (VORONOV and VINCE, 2012) and identification (FRIEDLAND, 2012) of women in politics.

In this study, the disruptive event can be considered the entrance of women in the political scenario. In 1934, women were allowed to run for political office in Brazil. This is considered a disruptive event that can create a new institutional logic, bringing into the Brazilian political environment a new logic based on values of incentive and support for the entry of women in the political scenario. This new logic opposes itself to the already existing one, which would be based on patriarchalism that prevailed before this disruptive event and strongly emphasized the presence of men in this scenario.

The results revealed that during the 2018 Brazilian electoral campaign, many people expressed negative emotions to these women, through the dissemination of fake news. In face of the institutionalization of a masculine environment on the political scenario, society expressed emotions of hatred and aggression against the candidates analyzed in this study, since they violated institutional arrangements of behaviors considerable acceptable in the dominant logic (CREED, HUDSON, OKHUYSEN et al., 2014). Despite this, two of these women candidates for political positions, and focus of this study, were elected as the most voted candidates in their states, reaching more votes than male competitors; the last one did not get elected despite obtaining an expressive amount of votes. However, it is perceived that the Brazilian society needs to make significant progress in supporting women's participation in politics and in many human rights issues in the country.

As mentioned before, the main contributions of this study involved (1) examining the role of emotions in a scenario of institutional complexity; (2) emphasizing that, although men and women sometimes occupy unequal roles in society (VERAS, 2018), changes are becoming increasingly necessary in all respects and; also (3) offering contributions about the "role social media might play in disrupting organizations in complex institutional settings (TOUBIANA and ZIETSMA, 2017), in this regard it can be considered a research gap, as few organizational scholars have examined this issue.

\section{ACKNOWLEDGMENT}

This study was financed in part by the Coordenação de Aperfeiçoamento de Pessoal de Nível Superior - Brasil (CAPES) Finance Code 001. 


\section{REFERENCES}

AMERICAN PSYCHIATRIC ASSOCIATION - APA. DSM-5: Manual diagnóstico e estatístico de transtornos mentais. Porto Alegre: Artmed Editora, 2014.

ARAÚJO, C. Gênero e acesso ao poder legislativo no Brasil: as cotas entre as instituições e a cultura. Revista Brasileira de Ciência Política, n. 2, p. 23-59, 2012.

ARAÚJO, C. Rotas de ingresso, trajetórias e acesso das mulheres ao legislativo: um estudo comparado entre Brasil e Argentina. Revista Estudos Feministas, v. 18, n. 2, p. 567-584, 2010.

BARSADE, S. G.; GIBSON, D. E. Why does affect matter in organizations? Academy of management perspectives, v. 21, n. 1, p. 36-59, 2007.

BAUER, N. M. Shifting standards: How voters evaluate the qualifications of female and male candidates. The Journal of Politics, v. 82, n. 1, p. 000-000, 2020.

BEAMAN, L. et al. Powerful women: does exposure reduce bias? The Quarterly journal of economics, v. 124, n. 4, p. 1497-1540, 2009.

BRASIL. Mulheres na política. Brasília, DF: Data Senado, 2014. Available at: $<$ https://www12.senado.leg.br/institucional/procuradoria/procpublicacoes/cartilha-mulheres-na-politica>. Accessed on: Nov. 20, 2018.

BRINKMANN, S. The interview. In: DEZIN, N.; LINCOLN, Y. S. (Eds.). Sage Handbook of Qualitative Research. Thousand Oaks: Sage Publications, 2018. p. 576-599.

CAJADO, A. F. R.; DORNELLES, T.; PEREIRA, A. C. Eleições no Brasil: uma história de 500 anos. Brasília, DF: Tribunal Superior Eleitoral, 2014.

COSTA, M.; SCHAFFNER, B. F. How Gender Conditions the Way Citizens Evaluate and Engage with Their Representatives. Political Research Quarterly, v. 71, n. 1, p. 46-58, 2018.

CREED, W. E. D. et al. Swimming in a sea of shame: Incorporating emotion into explanations of institutional reproduction and change. Academy of Management Review, v. 39, n. 3, p. 275-301, 2014.

CRESWELL, J. W.; CRESWELL, J. David. Research design: Qualitative, quantitative, and mixed methods approaches. Thousand Oaks: Sage publications, 2017.

DIMAGGIO, P. J.; POWELL, W. W. The iron cage revisited: Institutional isomorphism and collective rationality in organizational fields. American sociological review, p. 147-160, 1983.

FOLHA DE SÃO PAULO. Interrupções a Manuela geram debate sobre machismo. Folha de S. Paulo, São Paulo, June 26, 2018. Available at: <https://www1.folha.uol.com.br/poder/2018/06/interrupcoesa-manuela-geram-debate-sobre-machismo.shtml>. Accessed on: July 05, 2018.

FRIEDLAND, R. The Institutional logics Perspective: A new approach to culture, Structure, and Process. Management, v. 15, n. 5, p. 583-595, 2012.

GIBBS, G. Análise de dados qualitativos: coleção pesquisa qualitativa. Porto Alegre: Bookman Editora, 2009.

GILL, M. J.; BURROW, R. The function of fear in institutional maintenance: Feeling frightened as an essential ingredient in haute cuisine. Organization Studies, v. 39, n. 4, p. 445-465, 2018.
GRANT, I. et al. Historic sex-ratio imbalances predict female participation in the market for politicians. Journal of Economic Behavior \& Organization, v. 156, p. 144-165, 2018.

INSTITUTE FOR DEMOCRACY AND ELECTORAL ASSISTANCE IDEA. Gender quotas database. 2018. Available at: <https://www. idea.int/data-tools/data/gender-quotas/database>. Accessed on: June 11, 2019.

INTER-PARLIAMENTARY UNION. Woman in national Parliaments. 2019. Available at: <http://archive.ipu.org/wmn-e/classif.htm>. Accessed on: June 11, 2019.

LERNER, J. S.; TIEDENS, L. Z. Portrait of the angry decision maker: How appraisal tendencies shape anger's influence on cognition. Journal of behavioral decision making, v. 19, n. 2, p. 115-137, 2006.

MACHADO, C. L.; GONÇALVES, S. Nota técnica: a teoria institucional. In: CLEGG, S.; HARDY, C.; NORD, W. R. (Eds.). Handbook de Estudos Organizacionais. São Paulo: Ed. Atlas, 2007.

MEYER, J. W.; ROWAN, B. Institutionalized organizations: Formal structure as myth and ceremony. American journal of sociology, v. 83, n. 2, p. 340-363, 1977.

MIGUEL, L.; FEITOSA, F. O gênero do discurso parlamentar: mulheres e homens na tribuna da Câmara dos Deputados. Dados, v. 52, n. 1, p. 201-221, 2009.

NG, E.; MUNTANER, C. The effect of women in government on population health: An ecological analysis among Canadian provinces, 1976-2009. SSM-population health, v. 6, p. 141-148, 2018.

REYES-HOUSHOLDER, C. Women Mobilizing Women: Candidates' Strategies for Winning the Presidency. Journal of Politics in Latin America, v. 10, n. 1, p. 69-97, 2018.

RICHARDSON, R. J. Pesquisa social: métodos e técnicas. São Paulo: Atlas, 1999.

ROMERO, K.; KERSTENETZKY, C. L. Entre o altruísmo e o familismo: a agenda parlamentar feminina e as políticas família-trabalho (Brasil, 20032013). Revista Brasileira de Ciência Política, n. 18, p. 119-146, 2015.

SACCHET, T. Why gender quotas don't work in Brazil? The role of the electoral system and political finance. Colombia Internacional, n. 95, p. $25-54,2018$

SALDAÑA, J.; OMASTA, M. Qualitative research: Analyzing life. Thousand Oaks: Sage Publications, 2016.

SCOTT, W. R. Institutions and organizations: Ideas, interests, and identities. Thousand Oaks: Sage publications, 2013.

SILVA, A. C. B.; OLIVEIRA, E. C.; RIBEIRO FILHO, J. F. Revista Contabilidade \& Finanças - USP: uma comparação entre os períodos 1989/2001 e 2001/2004. Revista Contabilidade \& Finanças, v. 16, n. 39, p. 20-32, 2005.

SINGH, J. J. et al. Anger strays, fear refrains: The differential effect of negative emotions on consumers' ethical judgments. Journal of Business Ethics, v. 151, n. 1, p. 235-248, 2018.

STYCER, M. Vitória da desinformação. Folha de S. Paulo, São Paulo, July 01, 2018. Available at: <https://www1.folha.uol.com.br/colunas/ 
Women in politics: emotions and challenges in complex institutional dynamics
Camilla Fernandes | Mariane Lemos Lourenço Samantha Frohlich | Diogo Espejo da Silva

Flávia Obara Kai mauriciostycer/2018/07/vitoria-da-desinformacao.shtml>. Accessed on: Dec. 05, 2018.

TELES, M.A.A. Breve história do feminismo no Brasil e outros ensaios. São Paulo: Alameda Casa Editorial, 2017.

TOSI, M. A conquista do direito ao voto feminino. 2016. Available at: <https://www.politize.com.br/conquista-do-direito-ao-votofeminino/>. Accessed on: June 11, 2019.

TOUBIANA, M.; ZIETSMA, C. The message is on the wall? Emotions, social media and the dynamics of institutional complexity. Academy of Management Journal, v. 60, n. 3, p. 922-953, 2017.

TRIBUNAL SUPERIOR ELEITORAL - TSE. Mais de 16 mil candidatos tiveram votação zerada nas Eleições 2016. 2016. Available at: <http://www.tse.jus.br/imprensa/noticias-tse/2016/Novembro/maisde-16-mil-candidatos-tiveram-votacao-zerada-nas-eleicoes-2016>. Accessed on: June 11, 2019.

TRIBUNAL SUPERIOR ELEITORAL - TSE. Ministro Sergio Banhos determina ao Facebook remoção de vídeo contra Manuela
D’Ávila. 2018. Available at: <http://www.tse.jus.br/imprensa/ noticias-tse/2018/Outubro/ministro-sergio-banhos-determinaao-facebook-remocao-de-video-contra-manuela-davila>. Accessed on: Dec. 27, 2018.

VERAS, M. Calminha Querida. 2018. Available at: <http://www. aldeianago.com.br/outros-baianos/19617-calminha-querida-pormarcelo-veras>. Accessed on: July 07, 2018.

VORONOV, M.; VINCE, R. Integrating emotions into the analysis of institutional work. Academy of Management Review, v. 37, n. 1, p. 58-81, 2012.

VORONOV, M.; WEBER, K. The heart of institutions: Emotional competence and institutional actorhood. Academy of Management Review, v. 41, n. 3, p. 456-478, 2016.

ZAKAR, R.; ZAKAR, M. Z.; HAMID, N. Gender mainstreaming in politics: Perspective of female politicians from Pakistan. Asian Journal of Women's Studies, v. 24, n. 2, p. 224-245, 2018.

Camilla Fernandes

ORCID: https://orcid.org/0000-0001-6173-8613

Ph.D. student in the Postgraduate Program in Administration at the Federal University of Paraná (PPGADM- UFPR); Master in Administration from the Federal University of Paraná (UFPR); Bachelor of Business Administration from the Federal University of Santa Catarina (UFSC), Curitiba - PR, Brazil. E-mail: camillafernandes@ufpr.br

Mariane Lemos Lourenço

ORCID: https://orcid.org/0000-0003-2887-9232

Ph.D. in Psychology from the University of São Paulo (USP); Master in Psychology from the University of São Paulo (USP); Graduated in Psychology at the Federal University of Paraná (UFPR); Professor at the Department of Administration and the Postgraduate Program in Administration at the Federal University of Paraná (PPGADM- UFPR), Curitiba-PR, Brazil. E-mail: marianellourenco@ufpr.br

Samantha Frohlich

ORCID: https://orcid.org/0000-0003-3679-8870

Ph.D. student in the Postgraduate Program in Administration at the Federal University of Paraná (PPGADM- UFPR); Master in Administration from the Federal University of Paraná (UFPR); Bachelor in Executive Secretariat from the State University of Western Paraná (UNIOESTE), Curitiba- PR, Brazil. E-mail: samanthafrohlich@ufpr.br

Diogo Espejo da Silva

ORCID: https://orcid.org/0000-0003-2396-9597

Bachelor of Business Administration from the Federal University of Paraná (UFPR); Bachelor of Biotechnology from the Pontifical Catholic University of Paraná (PUCPR), Curitiba-PR, Brazil. E-mail: diogo.espejo@ufpr.br

Flavia Obara Kai

ORCID: https://orcid.org/0000-0002-8087-487X

Master in Administration from the Federal University of Paraná (UFPR); Specialist in Marketing and Advertising Administration at the State University of Londrina (UEL); Bachelor of Social Communication- Public Relations at the State University of Londrina (UEL); Teacher-Tutor (DE) at the Pontifical Catholic University of Paraná (PUCPR), Curitiba- PR, Brazil. E-mail: flavia.obarakai@gmail.com 